\title{
Trends in evapotranspiration and water productivity of rice and wheat in different agroclimatic regions of Punjab, India
}

\author{
P. K.KINGRA ${ }^{1}$, S. S.KUKAL ${ }^{2}$ and SOM PAL SINGH ${ }^{1}$ \\ ${ }^{1}$ Department of Climate Change and Agricultural Meteorology, College of Agriculture \\ Punjab Agricultural University, Ludhiana 141004 \\ email:pkkingra@pau.edu
}

\begin{abstract}
Actual evapotranspiration ( $A E T$ ), grain yield and water productivity $\left(W P_{E T}\right)$ of rice and wheat were assessed in relation to changing climatic conditions over a period of 32-46 years for three locations (Ballowal Saunkhari, Ludhiana and Bathinda) in different agro-climatic regions of Punjab. A large variability in $A E T$ of rice and wheat were observed over the years with increasing trend at Ballowal Saunkhari and decreasing trend at Ludhiana and Bathinda. A linear increase in grain yield of rice and wheat was observed at all the three locations. This resulted a significant increasing trends in water productivity of both wheat and rice at all the stations. The water productivity of rice was negatively correlated with AET while water productivity of wheat had curvilinear relationship with AET.
\end{abstract}

Key words: Climate change, evapotranspiration, water productivity, wheat, rice

The climate change, especially the global warming, has started affecting agricultural productivity to a great extent.Changes in temperature are expected to directly impact water requirements of plants. Mahmood (1997) reported 5 per cent increase in total seasonal evapotranspiration (ET) under $1^{\circ} \mathrm{C}$ warmer air temperature conditions. Agriculture, being the major water consumer, accurate estimates of crop water requirements are required for better planning of future water resources for higher input use efficiency. The rice-wheat cropping system occupies about 13.5 million hectares in south Asia and is one of the most important cropping system for food security in the region (Erenstein, 2009). The Indian Punjab, an important rice-wheat producing state in Indo-Gangetic plains, is the fertile land with semi-arid climatic conditions. The increased frequency of extreme weather events (Kaur et al, 2016) has started creating imbalances in the hydrological cycle and is resulting in large year-to-year fluctuations in crop yields (Kingra 2016 a \& b) and hence water productivity (Kingra and Kukal 2013) during the recent past.

The climatic variability and its trends in Punjab and its effect of crop production have been studied by many workers but trends in evapotranspiration and water productivity have not been reported. Hence, the present investigation was carried out to assess the long-term trend in actual evapotranspiration and water productivity of ricewheat system in different agroclimatic regions of Indian Punjab.

\section{MATERIALS AND METHODS}

The long-term weather data were collected for Ludhiana (1970-2015) representing the semi-arid region, Bathinda (1977-2015) representing arid and Ballowal Saunkhari(1984-2015) representing the sub-humid region of Punjab. The long-term data on grain yields of wheat and rice crops for the corresponding period in all the three regions was obtained from the secondary sources. The agroclimatic features of three stations are presented in Table 1.

The potential evapotranspiration (PET) was computed by Papadakis method (Papadakis, 1965) already validated for PET computations in the study site (Kingra et al., 2002).

$$
\text { PET }=\frac{0.5625\left(\mathrm{e}_{\max }-\mathrm{e}_{\min -2}\right) \times 10}{\text { No. of days in month }}
$$

Where, PET is potential evapotranspiration $\left(\mathrm{mm} \mathrm{day}^{-1}\right), \mathrm{e}_{\max }$ is saturation vapour pressure $(\mathrm{SVP})(\mathrm{mb})$ at daily maximum temperature, $\mathrm{e}_{\text {min-2 }}$ is $\mathrm{SVP}(\mathrm{mb})$ at dew point temperature and 0.5625 is Papadaki's constant. The actual evapotranspiration (AET) was computed as the product of PET and crop coefficient $\left(\mathrm{K}_{\mathrm{c}}\right)$ for rice and wheat crops as reported by Kingra et al.(2004).

The water productivity $\left(\mathrm{WP}_{\mathrm{ET}}\right)$ for wheat and rice crops was computed as the ratio of grain yield and AET, expressed in $\mathrm{g} \mathrm{kg}^{-1}$. 
Table 1: Geographical and meteorological features of three locations representing three agroclimatic regions of Punjab

\begin{tabular}{llll}
\hline Feature & $\begin{array}{l}\text { Ballowal Saunkhari } \\
\text { (Sub-humid region) }\end{array}$ & $\begin{array}{l}\text { Ludhiana } \\
\text { (Semi-arid region) }\end{array}$ & $\begin{array}{l}\text { Bathinda } \\
\text { (Arid region) }\end{array}$ \\
\hline Latitude $(\mathrm{N})$ & $31^{\circ} 6^{\prime} 5^{\prime \prime}$ & $30^{\circ} 54^{\prime} 33^{\prime \prime}$ & $30^{\circ} 12^{\prime} 32^{\prime \prime}$ \\
Longitude (E) & $76^{\circ} 23^{\prime} 26^{\prime \prime}$ & $75^{\circ} 48^{\prime} 22^{\prime \prime}$ & $74^{\circ} 57^{\prime} 9^{\prime \prime}$ \\
Altitude $(\mathrm{m})$ & 355 & 247 & 211 \\
Annual max. temperature $\left({ }^{\circ} \mathrm{C}\right)$ & 30.0 & 29.8 & 31.1 \\
Annual mini. temperature $\left({ }^{\circ} \mathrm{C}\right.$ & 16.3 & 16.6 & 16.9 \\
Annual average rainfall $(\mathrm{mm})$ & 1025.4 & 753.3 & 548.9 \\
Annual average PET $(\mathrm{mm})$ & 1802.0 & 1898.0 & 2079.0 \\
\hline
\end{tabular}

Table 2: Trends in actual evapotranspiration, grain yield and water productivity of rice and wheat in different agroclimatic regions of Punjab

\begin{tabular}{llll}
\hline Parameter/crop & Ballowal Saunkhari & Ludhiana & Bathinda \\
\hline Actual AET (mm) & & & \\
Rice & $\mathrm{y}=2.052 \mathrm{x}+689.0$ & $\mathrm{y}=-3.414 \mathrm{x}+802.0$ & $\mathrm{y}=-3.950 \mathrm{x}+960.9$ \\
& $\mathrm{R}^{2}=0.079$ & $\mathrm{R}^{2}=0.348$ & $\mathrm{R}^{2}=0.183$ \\
Wheat & $\mathrm{y}=1.111 \mathrm{x}+427.6$ & $\mathrm{y}=-0.333 \mathrm{x}+401.5$ & $\mathrm{y}=-0.333 \mathrm{x}+401.5$ \\
& $\mathrm{R}^{2}=0.073$ & $\mathrm{R}^{2}=0.020$ & $\mathrm{R}^{2}=0.020$ \\
Grain yield (t ha-1) & & & \\
Rice & $\mathrm{y}=0.081 \mathrm{x}+2.442$ & $\mathrm{y}=0.049 \mathrm{x}+2.981$ & $\mathrm{y}=0.035 \mathrm{x}+3.019$ \\
& $\mathrm{R}^{2}=0.754$ & $\mathrm{R}^{2}=0.823$ & $\mathrm{R}^{2}=0.702$ \\
Wheat & $\mathrm{y}=0.056 \mathrm{x}+2.431$ & $\mathrm{y}=0.036 \mathrm{x}+2.948$ & $\mathrm{y}=0.064 \mathrm{x}+2.402$ \\
& $\mathrm{R}^{2}=0.856$ & $\mathrm{R}^{2}=0.572$ & $\mathrm{R}^{2}=0.847$ \\
Water productivity $\left(\mathbf{g ~ k g}^{-1}\right)$ & & & \\
Rice & $\mathrm{y}=0.006 \mathrm{x}+0.359$ & $\mathrm{y}=0.007 \mathrm{x}+0.364$ & $\mathrm{y}=0.005 \mathrm{x}+0.314$ \\
& $\mathrm{R}^{2}=0.625$ & $\mathrm{R}^{2}=0.705$ & $\mathrm{R}^{2}=0.575$ \\
Wheat & $\mathrm{y}=0.016 \mathrm{x}+0.576$ & $\mathrm{y}=0.013 \mathrm{x}+0.748$ & $\mathrm{y}=0.017 \mathrm{x}+0.48$ \\
& $\mathrm{R}^{2}=0.694$ & $\mathrm{R}^{2}=0.754$ & $\mathrm{R}^{2}=0.785$ \\
\hline
\end{tabular}

\section{RESULTS AND DISCUSSION}

\section{Trends in actual evapotranspiration}

The AET of rice and wheat at Ballowal Saunkhari increased over the years (Table 2). Over a period of about three decades the AET of rice was highest $(903.6 \mathrm{~mm})$ in 1987 and lowest $(599.4 \mathrm{~mm}$ ) in 1988 with increasing trend of $2.05 \mathrm{~mm}$ per year. Similarly, the AET of wheat was highest (517.0 mm) in 2001-02 and lowest (375.6 mm)in 1989-90 with increasing trend of $1.11 \mathrm{~mm}$ per year.

Temporal variability analysis of AET of rice at Ludhiana indicated a decreasing trend over the years (Table 2). Over a period of four decades, lowest AET of rice was $617.1 \mathrm{~mm}$ in 2011-12 and highest (915.3 mm) in 1987-88 with decreasing trend of $-3.41 \mathrm{~mm}$ per year. The AET of wheat at Ludhiana was also found to decrease over the years. The lowest AET of wheat was $324.8 \mathrm{~mm}$ in 1997-98 and highest was $462.3 \mathrm{~mm}$ in 1970-71 with decreasing trend of $-0.33 \mathrm{~mm}$ per year.

Temporal variability analysis of AET of rice and wheat at Bathinda also indicated a decreasing trend (Table 2). Over a period of 38 years, the AET of rice was highest $(1121.3 \mathrm{~mm})$ in 1987 and lowest $(651.7 \mathrm{~mm})$ in 1993 with decreasing trend of $-3.95 \mathrm{~mm}$ per year. Similarly, the highest AET of wheat was $553.0 \mathrm{~mm}$ in 1992-93 and lowest of $361.8 \mathrm{~mm}$ during 1997-98 with decreasing trend of $0.33 \mathrm{~mm}$ per year.

Thus, a large variability in AET of rice and wheat crops has been observed in different agroclimatic regions of Punjab over the years. It has increasing trend in the sub- 

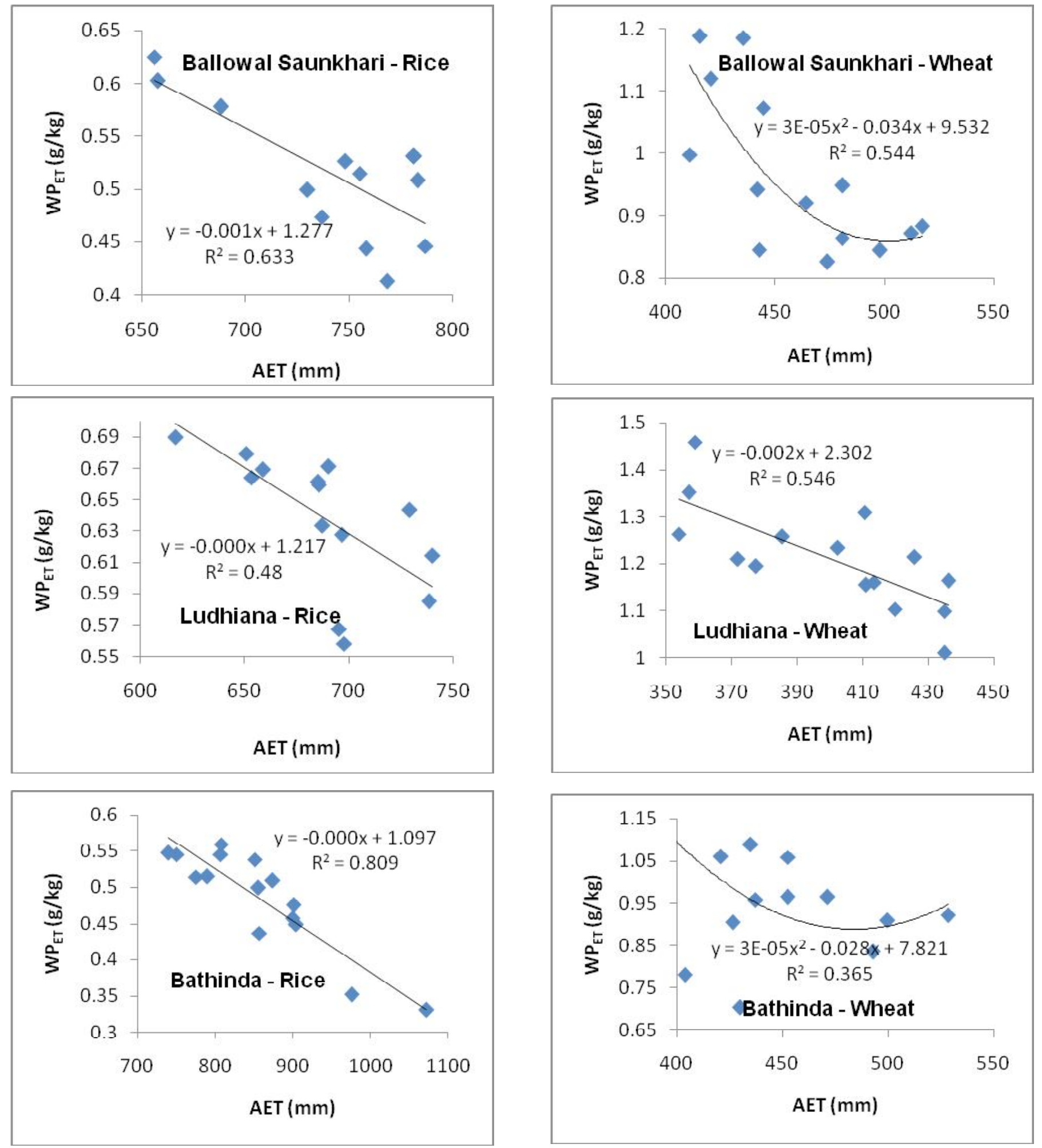

Fig.1: Relation between actual evapotranspiration (AET) and water productivity $\left(\mathrm{WP}_{\mathrm{ET}}\right)$ of rice and wheat during recent years (2000-01 to 2014-15) in different agroclimatic regions of Punjab 
humid region, whereas in the semi-arid and arid regions the AET of both rice and wheat has decreasing trends. Large year-to-year variations in AET of rice and wheat crops indicated the significant impact of weather variability on crop water requirements.

\section{Trends in grain yield}

Temporal variability analysis of grain yield of rice and wheat at Ballowal Saunkhari indicated a linear increase over the time (Table 2). The highest rice yield $\left(4.15\right.$ tha $\left.^{-1}\right)$ was observed during 2009-10 and lowest (2.26 tha $\left.{ }^{-1}\right)$ during 1988-89 with overall increasing trend of $0.08 \mathrm{~kg} \mathrm{ha}^{-1} \mathrm{y}^{-1}$. Similarly, the highest wheat yield $\left(5.16\right.$ tha $\left.^{-1}\right)$ was recorded during 2011-12 and lowest (2.12 tha $\left.{ }^{-1}\right)$ during 1984-85 with increasing trend of $0.056 \mathrm{~kg} \mathrm{ha}^{-1} \mathrm{y}^{-1}$. Linear increase in productivity can be attributed mainly to the improved cultivars and production technology, but large year to year fluctuations reflect the role of weather variability.

The grain yield trends of rice and wheat at Ludhiana indicated a linear increase over a period of 46 years (Table 2). The rice yield ranged from 1.8 tha $^{-1}$ in 1970 to 4.69 tha $^{-1}$ in 2009 with overall increasing trend of $0.049 \mathrm{~kg} \mathrm{ha}^{-1}$ $\mathrm{y}^{-1}$.Temporal variability analysis of wheat yield also depicted linear increase over the time, ranging from 2.82 tha $^{-1}$ in 1975 76 to 5.38 tha $^{-1}$ in $2011-12$ at the rate of $0.064 \mathrm{~kg}$ ha $^{-1} \mathrm{y}^{-1}$.

The grain yield of wheat and rice at Bathinda indicated a linear increase over a period of 38 years. The highest rice yield of 4.58 tha $^{-1}$ was observed during 2009-10 and the lowest of 2.62 tha $^{-1}$ during 1979-80 with increasing trend of $0.035 \mathrm{~kg} \mathrm{ha}^{-1} \mathrm{y}^{-1}$. Similarly, highest wheat grain yield of 5.0 tha $^{-1}$ was recorded during 2011-12 and lowest of 2.27 tha $^{-1}$ during 1983-84 with increasing trend of $0.035 \mathrm{~kg}$ $\mathrm{ha}^{-1} \mathrm{y}^{-1}$.

\section{Trends in water productivity ( $W P_{E P}$ )}

The evapotranspiration based water productivity $\left(\mathrm{WP}_{\mathrm{ET}}\right)$ of rice and wheat indicated a linear increase with time at all the three stations (Table 2). The $\mathrm{WP}_{\mathrm{ET}}$ of rice ranged between $0.253 \mathrm{gkg}^{-1}$ in $1987-88$ to $0.625 \mathrm{gkg}^{-1}$ in $2008-09$ at Ballowal Saunkhari; between at Ludhiana and between 0.242 in $1979-80$ to $0.594 \mathrm{~g} \mathrm{~kg}^{-1}$ in 1993-94 at Bathinda. Similarly, the $\mathrm{WP}_{\mathrm{ET}}$ of wheat ranged between 0.431 to 1.188 $\mathrm{g} \mathrm{kg}^{-1}$ at Ballowal Saunkhari; between 0.709 to $1.458 \mathrm{~g}$ $\mathrm{kg}^{-1}$ at Ludhiana and between 0.444 to $1.291 \mathrm{~g} \mathrm{~kg}^{-1}$ at Bathinda.

\section{Relation between $A E T$ and $W P_{E T}$}

Although a linear increase in $\mathrm{WP}_{\mathrm{ET}}$ of rice and wheat was observed over the years, but it may be attributed mainly to the linear increase in yield of rice and wheat. Yan and $\mathrm{Wu}$ (2014) also concluded that improvements in crop water productivity of winter wheat have resulted from improvements in crop varieties and crop husbandry, rather than reductions in water consumption. The decrease in AET of rice during four decades also played a role in enhancing the crop water productivity. The $\mathrm{WP}_{\mathrm{ET}}$ of rice was significantly and negatively correlated with AET at all the locations. Similarly, the $\mathrm{WP}_{\mathrm{ET}}$ of wheat was also found to be negatively correlated with AET. The relationship between $\mathrm{WP}_{\mathrm{ET}}$ and AET of rice and wheat also indicates that with decrease in AET, $\mathrm{WP}_{\mathrm{ET}}$ increases (Fig. 1). Thus, by reducing the evaporation losses in the fields, there is a good scope for enhancing their $\mathrm{WP}_{\mathrm{ET}}$.

\section{CONCLUSIONS}

The results of the study indicated that the increase in water productivity of rice and wheat crops over the years does not indicate any saving of water but it can be attributed to linear increase in yield of both the crops. As the $\mathrm{WP}_{\mathrm{ET}}$ of rice and wheat has been observed to be negatively correlated with AET, thus, by reducing the evaporation losses in the fields, there is a good scope for enhancing their $\mathrm{WP}_{\mathrm{ET}}$.

\section{REFERENCES}

Erenstein, O.(2009). Zero tillage in the rice-wheat systems of the Indo-Gangetic Plains: A review of impacts and sustainability implications. IFPRI Discussion Paper. Washington, D.C.: International Food Policy Research Institute.

Kaur, P., Kaur, N. and Singh, H. (2016). Near- and long-term projected changes in extreme weather events in Ludhiana district of Punjab. Agric. Res. J., 53 (3): 360366.

Kingra, P. K.(2016a). Climate variability impacts on wheat productivity in central Punjab. J. Agrometeorol., 18 (1): $97-99$.

Kingra, P. K.(2016b). Climate variability impact on rice productivity in central Punjab. J. Agrometeorol., 18(1): $146-148$.

Kingra, P. K. and Kukal, S. S. (2013).Impact of climate change on evapo-transpiration and water productivity of wheat in central Punjab. J. Res. Punjab Agric. Univ., 50 (3 \& 4):181-183. 
Kingra, P. K., Hundal, S. S. and Sharma, P. K. (2004). Characterization of crop coefficients for wheat and rice crops in Punjab. J. Agrometeorol., 6: 58-60.

Kingra,P. K.,Prabhjyot-KaurandHundal, S. S. (2002). Estimation of PET by various methods and its relationship with mesh covered pan evaporation at Ludhiana. $J$. Agrometeorol., 4: 143-149.

Mahmood, R.(1997). Impacts of air temperature variations on the boro rice phenology in Bangladesh: implications for irrigation requirements. Agric. Forest Meteorol., 84 (34), $233-247$.

Papadakis, J.(1965). Potential Evapotranspiration. Buenos Aires, 54.

Yan, N. and Wu, B. (2014). Integrated spatial-temporal analysis of crop water productivity of winter wheat in Hai Basin. Agric. Water Manage., 133: 24-33. 